Yasemin Kılıç Öztürk ${ }^{l}$, Melike Arabact ${ }^{1}$ Pınar Köksal', Umut Gök Balcıl,

Haluk Mergen ${ }^{l}$, Kurtuluş Öngel ${ }^{2}$

${ }^{1}$ Tepecik Education and Research Hospital, Department of Family Medicine, İzmir, Turkey

${ }^{2}$ İzmir Katip Çelebi University, Faculty of Medicine,

Department of Family Medicine, İzmir, Turkey

\title{
Obesity concomitant with eventration of the diaphragm: a case report
}

Abstract

Introduction: Eventration of the diaphragm is a disorder in which all or part of the diaphragmatic muscle is replaced by fibroelastic tissue. The incidence of evantration is uncertain, although one paper reports that this entity is detected in 1 per 1400 chest radiographies. This article reports a case of right-sided eventration of diaphragm in 70 years old obese woman who was admitted to our institution with complaints of recurrent cough and sweating.

Case report: A 70 year-old obese woman was admitted to Izmir Tepecik Education and Research Hospital Family Medicine Obesity Polyclinic with complaints of recurrent cough and sweating symptoms for the last few months. Reduction in lungs sounds on the right side and dullness were detected by the physical examination. X-ray chest in posteroanterior (PA) and lateral view exhibited elevation of the right diaphragm. During hospitalization patient was treated with Valsartan $(320 \mathrm{mg})+$ Hydrochlorotiazide $(12,5 \mathrm{mg})$ combination for hypertension; atorvastatine $40 \mathrm{mg}$ for hyperlipidemia; asetylsistein for productive cough and alginic acid as an antacid. She had had a 1800 kilocalories diet without salt. Upper respiratory tract symptoms were regressed and blood pressure was at the normal range. She was hospitalized for 15 days for diagnosis and weight reduction as well. Thus; the patient was discharged from the institution with the information about diaphragm eventration and obesity, and advised of their symptoms, warnings and guarding herself against trauma, and referred to Chest Diseases polyclinic.

Conclusion: Respiratory symptoms such as recurrent cough and upper respiratory infections are the most common complaints in the patients' visits to family medicine practitioners. Although eventration of the diaphragm is rarely seen and usually is asymptomatic; it should be kept in mind as a reason of recurrent cough especially in obese patients who have vertebral pathologies or history of surgery.

\section{Introduction}

Eventration of the diaphragm is a disorder in which diaphragmatic muscle is completely or partially replaced by fibroelastic tissue. The diaphragm retains its continuity and attachments to the costal margin. However; the weakened hemi diaphragm and the organs underlying are displaced into the thorax, and may compromise breathing ${ }^{1}$. It is more common on the left side, with equal prevalence in men and women ${ }^{2,3}$. With diaphragmatic hernia, in contrast, this continuity between the diaphragm and the costal margin is disrupted. The incidence of eventration is uncertain; although in one report, the condition was detected in 1 per 1400 patients who had chest radiographs. Congenital eventration can be isolated, although they are sometimes associated with other developmental defects, such as cleft palate, congenital heart disease, situs inversus or undescended testicle. The most common cause of acquired eventration is injury to the phrenic nerve, resulting from either a traumatic birth or previous surgery. The loss of contractility leads to muscle atrophy with elevation of the hemi diaphragm. The defect in congenital eventration can be partial or diffuse. Diffused effects tend to be unilateral and occur more commonly on the left side. Majority 
of patients are asymptomatic, especially when the eventration is localized. Though, they may become symptomatic during long bed-rests or severe physical exercise ${ }^{4,5}$. However respiratory signs are the most common, some patients can show gastrointestinal abnormalities. They include feeding difficulty, nausea, vomiting, or indigestion. Gastrointestinal findings are related to rotation of the gastric fundus and, sometimes, of the bowel into the elevated diaphragm. The diagnosis of eventration is suspected when a hemi diaphragm appears elevated on a frontal or lateral chest radiograph. Other radiographic findings, that may be seen include, shift of the mediastinum, atelectasis and elevation of the stomach. The main treatment modality is surgery, but if patient is asymptomatic and pulmonary functional tests are within the normal range; preferred choice are x-ray follow ups.

\section{Case report}

A 70 year-old obese woman was admitted to Izmir Tepecik Education and Research Hospital Family Medicine Obesity Polyclinic with complaints of recurrent cough and sweating, for the last few months.

The patient complained of atypical chest pain, pain in the neck and back. She had a history of appendectomy and hysterectomy. She had a history of recurrent upper respiratory infections, hyperlipidemia and hypertension. Although she was treated with clarithromycin and acetylcystein, cough was persistent. The cough was minimally productive with whiteyellowish sputum. Patient did not have fever, weight loss, shortness of breath, or fatigue. She had no significant exposure to occupational dust or chemicals and tobacco smoke. History was negative for allergy. Family history was negative for malignancies, tuberculosis, asthma and allergy.

On initial examination, temperature was $36,7^{\circ} \mathrm{C}$, heart rate 78 beats/min, arterial pressure $130 / 80 \mathrm{mmHg}$, respiratory frequency $20 \mathrm{bpm}$, weight $96 \mathrm{~kg}$, height $1.60 \mathrm{~m}$, and body mass index (BMI) $37,5 \mathrm{~kg} / \mathrm{m}^{2}$. Reduction in lungs sounds on the right side and dullness were detected by the physical examination. There were no rhonchi, wheezing or rales. Otorhinolaryngological and cardiovascular findings were normal on examination. Lymphadenopathy was not detected. Peripheral pulses were normal. Laboratory findings showed high cholesterol levels (total cholesterol $265 \mathrm{mg} / \mathrm{dL}$, low density lipids $196 \mathrm{mg} / \mathrm{dL}$, High density lipids $52 \mathrm{mg} / \mathrm{dL}$ ), leucocytosis (WBC $13.6 \times 10 \square / \mathrm{L})$ and high sedimentation rate $(67 \mathrm{~mm} / \mathrm{h}$ ) which were compatible with her previous upper respiratory tract infection and obesity. Other biochemical tests were at normal range (fasting glucose: $89 \mathrm{mg} / \mathrm{dl}$; aspartate transaminase $18 \mathrm{U} / \mathrm{L}$; alanin transaminase $13 \mathrm{U} / \mathrm{L}$; alkaline phospatase 92U/L: gamma glutamyl transferase $12 \mathrm{U} / \mathrm{L}$; lactate dehydrogenase 242U/L; albumin: $4 \mathrm{~g} / \mathrm{dl}$; globulin: $3.5 \mathrm{~g} / \mathrm{dl}$. X-ray chest in posteroanterior (PA) and lateral view demonstrated elevation of the right hemi diaphragm (Image 1a, Image 1b).

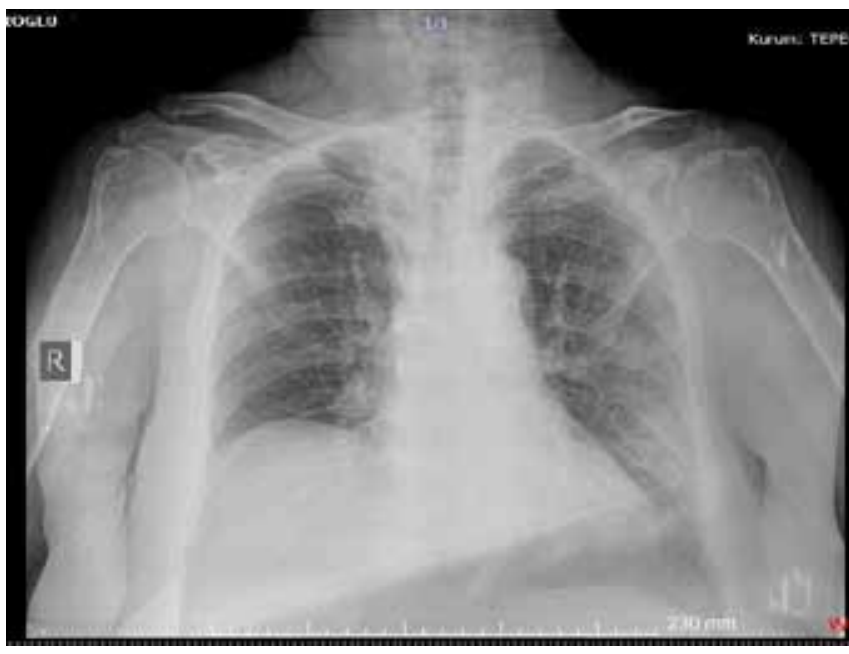

Image 1a. A hemidiaphragm appears elevated on a frontal chest radiograph

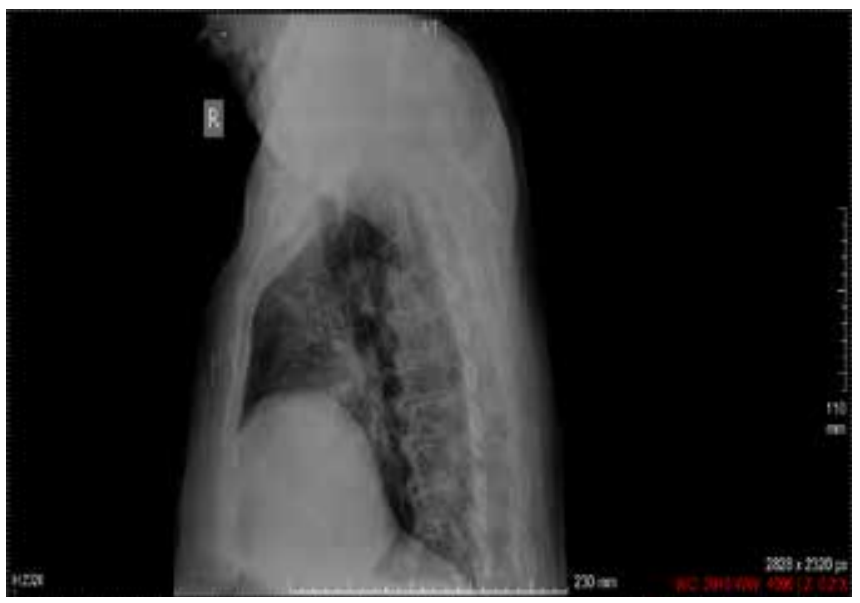

Image 1b. A hemi diaphragm appears elevated on a lateral chest radiograph

Computerized tomography (CT) scan of the chest confirmed right diaphragmatic eventration, increased pulmonary arterial diameter and thoracic spondylosis (image 1a, image 1b). On the pulmonary function tests (PFT), FEV1/FVC was 76.9 and FVC was 2.47, which is compatible with age. Electrocardiography was normal with a normal sinus rhythm. Echocardiography was performed to rule out a cardiac pathology because of atypical chest pain and pulmonary arterial dilatation detected by $\mathrm{CT}$. Ejection fraction was $60 \%$ and left ventricular concentric hypertrophy was detected. Due to the cardiological consultation, echocardiography findings were coherent with her hypertension history. The consultant suggested a myocardial perfusion scintigraphy after discharge from the hospital. Increased parenchymal echogenicity due to hepatic steatosis was reported by ultrasonography. She had a physical therapy specialist's consultation for the pains. The 
muscle strength was recorded as 5 points and she was told to have a follow up at the physiotherapy outpatient clinic for the thoracic scoliosis. Pulmonologists consultation was done; and there was no need for surgery due to the physical examination findings and PFT. Follow up at the polyclinic was suggested.

During hospitalization patient was treated with Valsar$\tan (320 \mathrm{mg})+$ Hydrochlorotiazide $(12,5 \mathrm{mg})$ combination for hypertension; atorvastatine $40 \mathrm{mg}$ for hyperlipidemia; asetylsistein for productive cough and alginic acid as an antacid. She had an 1800 kilocalories diet without salt. Upper respiratory symptoms were regressed and blood pressure was within normal range. She was hospitalized for 15 days for diagnosis and weight reduction. She reduced weight for $2 \mathrm{ki}-$ lograms and BMI was 36.7 at time of the discharge. Thus; the patient was discharged from the institution by the information about diaphragm eventration and obesity, their symptoms, warnings and guarding herself against trauma, and redirected to Chest Diseases polyclinic. She was scheduled for follow ups at obesity and physiotherapy polyclinics and was advised to continue treatment and diet used during hospitalization.

Cardiology polyclinic control with a myocardial perfusion scintigraphy was recommended. She was informed about having the risk of sleep apnea and to admit to sleep disorder policlinic because she had the emergency signs of apnea.
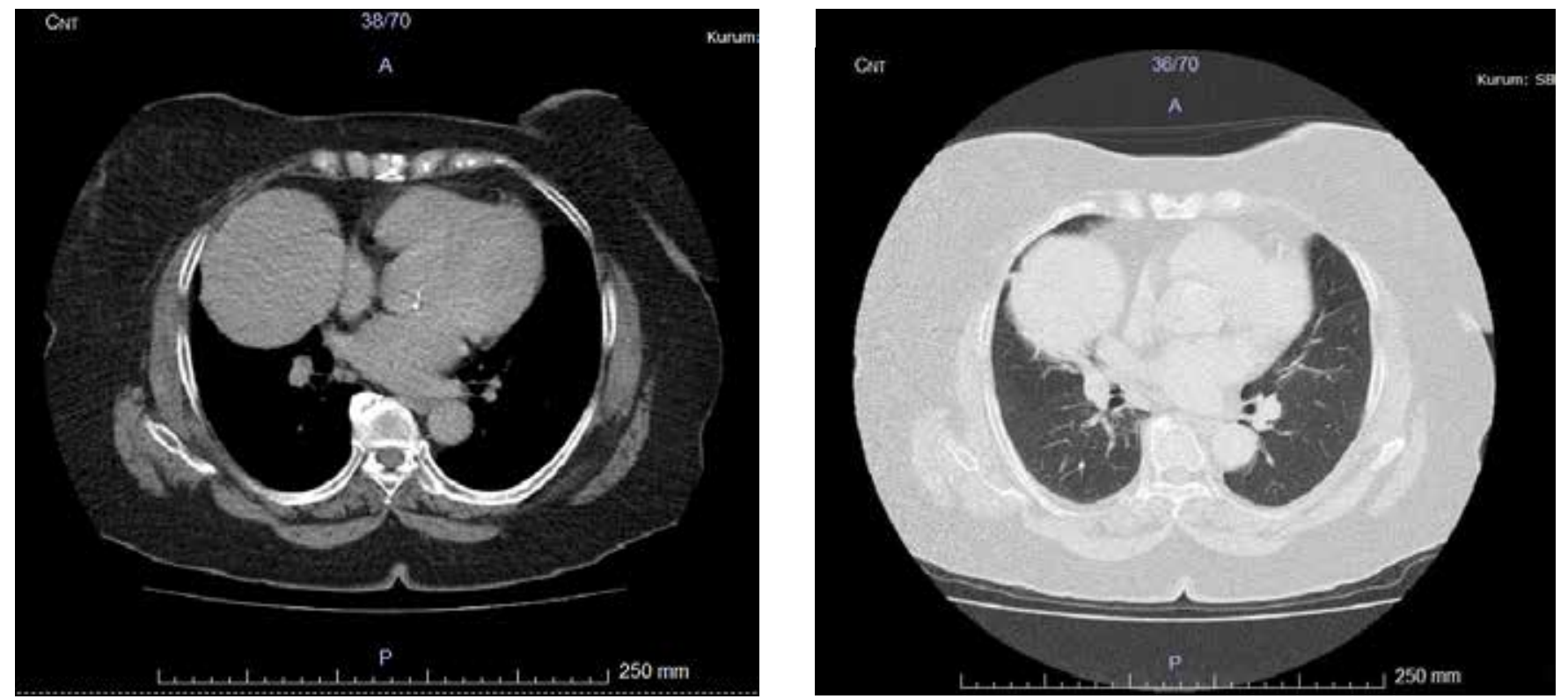

Image 2a-Image $\mathbf{2 b}$. $\mathrm{CT}$ of the chest

\section{Discussion}

Eventration of the diaphragm presents nearly 5\% of the diaphragm anomalies and is commonly seen in newborns congenitally. It is diagnosed fairly rare in adults, and common form in adults is acquired eventration ${ }^{6}$. In this case, the patient was diagnosed in old age and there were no significant complains proceeding from childhood. Although complete eventration of diaphragm usually occurs on the left side, this case was seen on the right side as a rare form. The most common cause of acquired eventration is idiopathic; however injury to the phrenic nerve, resulting from traumatic birth, vertebral pathology, neuromuscular diseases, tumors or a history of thoracic surgery should be evaluated ${ }^{7}$. In this case patient had thoracic spondylosis. Eventration of diaphragm in adults tends to be asymptomatic, and diagnosis is usually incidental, on X-ray chest screening ${ }^{8}$. However; history of recurrent respiratory infections and cough were present in the case. These symptoms might be attributed to obesity, as a result of increased intra-abdominal pressure. Sometimes these symptoms are associated with lung cancer, tuberculosis and allergy (asthma, extrinsic allergens or rhinitis) ${ }^{9}$. There was no family history of cancer, tuberculosis, or asthma. Also, there was no exposure to allergens, dust or chemicals. Fever, fatigue and weight loss are the principle findings in pneumonia and tuberculosis but they were excluded in the patient ${ }^{9}$. Eventration of diaphragm was detected by X-ray chest examination, a definitive method for diagnosis of eventration, and other differential diagnosis were excluded.

Treatment of diaphragm eventration is surgical correction of diaphragm according to the results of PFT and patient's clinical findings. In some studies, it has been reported that asymptomatic patients with diaphragm eventration could be recovered spontaneously, during radiological follow up ${ }^{7}$. 
In this case, PFT was in normal range and the patient was mildly symptomatic, therefore radiological follow up was decided. Weight loss is recommended for obese patients with eventration in order to decrease intraabdominal pressure and reduce complaints. Thus diet and exercise was suggested for the patient.

\section{Conclusion}

Eventration of the diaphragm occurs when all or part of the diaphragmatic muscle is replaced by fibroelastic tissue. In this condition, although the diaphragm retains its continuity and attachments to the costal margin, the weakened hemi diaphragm is displaced into the thorax, which can compromise breathing. Respiratory symptoms, such as recurrent cough and upper respiratory infections are the most common complaints of the patients admitting to Family Medicine Practitioners. Although eventration of the diaphragm is rarely seen and is usually asymptomatic; it should be kept in mind as a reason of recurrent cough, especially in obese patients with vertebral pathology or history of surgery.
Yasemin Kılıç Öztürk', Melike Arabacı', Pınar Köksal', Umut Gök Balcl ${ }^{l}$, Haluk Mergen ${ }^{l}$,Kurtuluş Öngel ${ }^{2}$

${ }^{1}$ Тепечик истраживачко-образовна болница, Одељење породичне медицине, Измир, Турска ${ }^{2}$ Измир Катип Челеби Универзитет, Медицински фалултет, Одељење породичне медицине, Измир, Турска

\section{Евентрација дијафрагме код гојазне особе: Приказ случаја}

\section{Кључне речи:}

лечење хроничних болести, исхрана и метаболизам

\section{Сажетак}

Увод. Евентрација дијафрагме је поремећај у коме је мишићно ткиво дијафраме делимично или у потпуности замењено фиброеластичним ткивом. Инциденија евентрације није поуздано утврђена иако неки радови наводе да се среће на једној од 1.400 радиографија торакса. У овом раду приказан је случај десностране евентрације дијафрагме код седамдесетогодишње гојазне жене, која је примљена на нашу клинику због рекурентног кашља са презнојавањем.

Приказ случаја. Седамдесетогодишња гојазна жена је примљена у поликлинику за гојазност на одељењу опште медицине. Главне тегобе су биле рекурентни кашаљ и појачано знојење у трајању од последњих неколико месеци. Физикалним прегледом нађени су ослабљен дисајни шум и перкуторна тмулост на десној страни. На $P A$ и профилној радиографији торакса уочена је Елевација десне хемидијафрагме. Током хоспитализације хипертензија је лечена комбинацијом валсартана $(320 \mathrm{mg})$ и хидрохлортијазида $(12,5 \mathrm{mg})$, хиперлипидемија аторвастатином (40 $\mathrm{mg}$ ), због продуктивног кашља је примала ацетилцистеин, а као антацид коришћен је алгинат. Исхрана је била ограничена на 1.800 калорија, без соли. Симптоми горњег респираторног тракта су се смањили, а притисак је био у нормалним границама. Била је хоспитализована 15 дана ради дијагностичког испитивања и редукције телесне тежине. Пацијенткиња је отпуштена из болнице и информисана о евентрацији дијафрагме, гојазности, симптомима које изазивају, и упозорена је да се чува траума. Упућена је на поликлинику за плућне болести.

Закључак. Респираторни симптоми као што су рекурентни кашаљ и инфекције горњих респираторних путева, најчешће су тегобе пацијената који се јављају лекару опште медицине. Иако се евентрација дијафрагме ретко виђа и обично је асимптоматска, треба помислити и на њу као узрок рекурентног кашља, посебно код гојазних пацијената са патолошким променама на пршљеновима или ранијим хируршким интервенцијама. 


\section{References}

\section{Literatura}

1. Mouroux J, Venissac N, Leo F, Alifano M, Guillot F. Surgical treatment of diaphragmatic eventration using videoassisted thoracic surgery: a prospective study. Ann Thorac Surg 2005;79:308-12.

2. Bircan A, Çakır M, Öztürk Ö. İdiyopatik edinsel tek tarafl diyafragma evantrasyonu: Olgu sunuтu. SDU Tip Fak Derg 2011;18(4):132-5.

3. Gürkök S, Genç O. Diyafragma paralizisinde diyafragma uyarımı. Türkiye Klinikleri 2005;25:111-7.

4. Akar E. Diyafragma Evantrasyonları. J Clin Anal Med 2012;3(4):422-4.
5. Kansal AP, Chopra V, Chahal AS, Grover CS, Singh H, Kansal S. Right-sided diaphragmatic eventration: A rare entity. Lung India 2009;26(2):48-50.

6. Venuta F, Rendina EA. Diaphragm: anatomy, embryology, pathophysiology. In: Patterson GA, Pearson FG, Cooper JD, et al, editors. Pearson's Thoracic and Eosophageal Surgery. 3rd edition. St. Louis (MO): Elsevier; 2008.1367-79.

7. Kul C, Gürsoy S, Üçvet A, Er M, Nimet A. Diyafragma Evantrasyonu: Olgu Sunumu. İzmir Göğüs Hast Derg 2009;23(3): $159-63$.
8. Akar E. Clinical Experience with Diaphragmatic Eventrations. J Clin Anal Med 2012;3(4):422-4.

9. Ukaonu C, Cine-Gowdie S, Bergrab P. Persistent cough. Am Fam Physician. 2012 Jan 1;85(1):63-5.

Primljen • Received: Ispravljen • Corrected:

$15 / 08 / 2014$ Prihvaćen • Accepted: 